\title{
New Approach for the Success of Yala cultivation in Dry zone under Drought Condition
}

\begin{abstract}
R.M.B. Rajakaruna
Abstract: Agriculture Ministry statics show that while the targeted acreage for cultivation during Yala 2012 was 494100 hectares. Only 348761 hectares have actually been cultivated. The harvest is estimated at 1.25 million metric tons. However these figures are expected to see drastic change due to the drought weather condition experienced in most part of the country, specially the agricultural areas.
\end{abstract}

Of the cultivated lands, most paddy lands in the Anuradhapura and Polonnaruwa districts have been severely affected by the shortage of water. According to Agriculture ministry 5000 hectares of paddy lands in Kurunegala district have been completely destroyed by the drought.

Under the above situation, the farmers of the Irrigation schemes who are in Galgamuwa area in Kurunegala district have been harvested their maximum yield in Yala 2012.

This paper reviews the hydrological, meteorological records and strategies to examine the possibility of planning irrigation issues during Yala season 2012 in the Galgamuwa area.

\section{Introduction}

Sri Lanka is heavily dependent on agriculture and both rain-fed and irrigated agriculture form the backbone of rural livelihoods. Scientists have suggested that the overall rainfall received by Sri Lanka has decreased in many areas of the country. The established patterns of rainfall have changed and the distribution of rainfall in different parts of the country also appears to be undergoing changes. While the droughts cause delays in planting seasons and are responsible for crop damages.

According to current statistics, the total cultivated area in Sri Lanka is estimated at 1.86 million ha. About 632000 ha of this area is irrigated; the rest is rain-fed. Irrigated agriculture is mainly comprised of major irrigation schemes. In addition, there are numerous minor schemes, which can be identified as semi rain-fed systems. They include over 15,000 village tanks scattered across the dry zone areas of the country.

Irrigated agriculture in Sri Lanka has received a great deal of attention from policy makers over the past several decades, which culminated in the accelerated Mahaweli Development Program in the mid 1980s.

Majority of the irrigated land in Sri Lanka is used for paddy cultivation. The demand for water is high in paddy cultivation compared to many other crops. Water is essential for the preparation of land, and the planting and maintenance of the crop throughout the planting-harvest cycle.

There are significant efforts by governments over the past few years to establish new infrastructure, rehabilitate or renovate existing dams, reservoirs and canals, and promote agro wells and micro-irrigation technologies to meet the rising demand for agricultural water. Despite such efforts, however, the problem of water scarcity continues grow. In order to meet the future demands of agricultural water innovative approaches are needed. The demand for agricultural water has to be balanced with the municipal and industrial water demand. Maximize the use of rain water for land preparation in paddy cultivation is one of the strategy can be adopted for dry zone in yala. The development of crop varieties that demand less water is one possible strategy to manage competing demands for water. The selective adoption of technologies appropriate for small farmers is another tool. Planning and coordinating irrigation water is also very important to save the excess use of water. Farmer organizations, local institutions,

Eng. R.M.B. Rajakaruna, IESl(Final), Msc(IWRM)

Peradeniya, C.Eng, MIE(Sri Lanka), presently employed as Divisional Irrigation Engineer Minneriya DivisionPolonnaruwa, Irrigation Department. 
and state agencies such as the Agrarian Development Department, Department of Agriculture, Department of irrigation, and the Department of Meteorology all have an important role to play. They must work closely and share knowledge and information so that irrigation water can be better managed through an IWRM approach.

In this paper, my attempt to highlight questions often rose by farmers, when government officials attend cultivation meetings at the each cultivation season to draw up the cultivation calendar for the season. However, according to the way these cultivation meetings are scheduled, this vital issue does not crop up as normally cultivation meetings are held during the monsoonal rainy seasons, while the irrigation tanks are spilling. By that time most of the monsoonal rains and intermosoonal rains have been fallen and disappeared from farm lands and therefore become ineffective, in the command area. This process results in wastage of natural rain water. In order to remedy this situation, if the cultivation meeting is held before inter monsoonal rain; well in advance of the rainy season it might be possible to use the rainfall for land preparation. Experience gained in 2012 yala by Galgamuwa farmers are Good examples for planning cultivation to use rainwater to land preparation and get success under drought weather.

\section{The Climate Seasons in Sri Lanka}

The Climate of Sri Lanka is dominated by the Southwest and Northeast monsoons regional scale wind regimes. The Climate experienced during 12 months period in Sri Lanka can be characterized in to 4 climate seasons as follows.
1. First Intermonsoon Season ( March - April)

2. Southwest monsoon season ( May - September)

3. Second Intermonsoon season (October - November)

4. Northeast Monsoon season (December February)

\subsection{Rain fall variability in Galgamuwa area}

Galgamuwa Irrigation division is located in the Kurunegala administrative District of North western province. Rain fall pattern of Anuradhapura were considered to represent the study area in view of the similarities in topography, elevation, and observed rainfall patterns. Monthly rainfall values of Galgamuwa were obtained for the five year period 2008 t0 2012 for the study (figure 1). By considering the rainfall data of the area, government officials and farmers can be decided the date of commencement of cultivation. We can observe that during February, March April, first Inter monsoonal rains have fallen and gets about $300 \mathrm{~mm}$ $400 \mathrm{~mm}$ rainfall to Galgamuwa area. Month of May, June, July gets less rain fall about 50mm$100 \mathrm{~mm}$ to the area considered. 


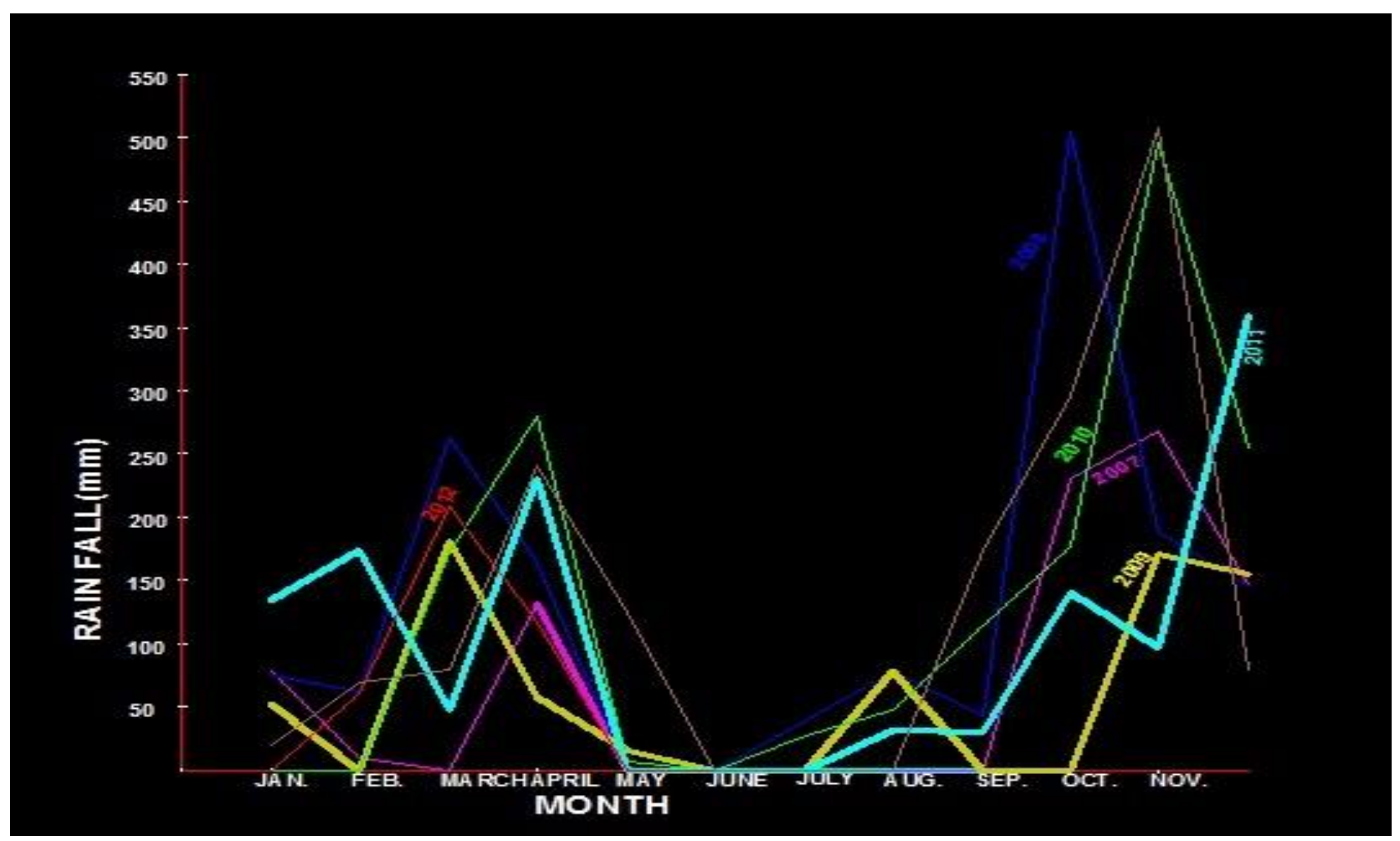

Figure 1- Rainfall Variability in Galgamuwa 2008 to 2012

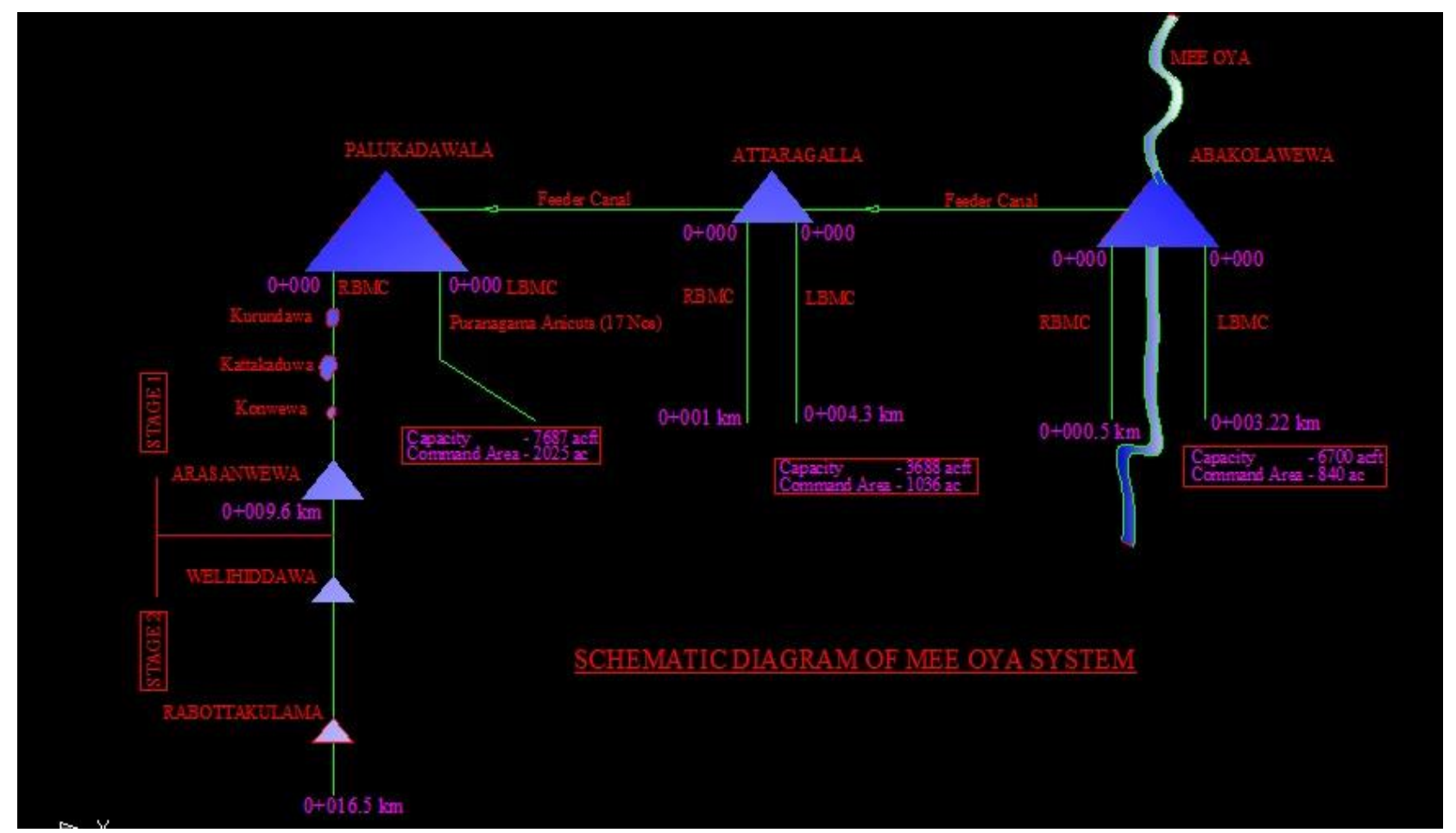

Figure 2 - Schematic Diagram of Mee Oya System 


\subsection{Climate over Sri Lanka during the Yala of} 2012

Large parts of the island were under drought this "Yala" which refers to the cultivation season that starts after the April-May rains. Impacts of droughts have led to shortages in drinking water in some areas and wells and rivers drying up and clapped landscapes. Farmers have been affected in large swathes of the island particularly in Polonnaruwa, Anuradhapura, Ampara, Kurunegala and Batticaloa districts.

The sowing and harvesting of the principal crop of rice takes place during the two cultivation seasons, Maha (starting in October) and Yala (starting end of April). During "Maha", the farmlands usually receive sufficient water to cultivate all rice fields whereas during "Yala", farmlands usually receive only enough water to cultivate about half the fields and farmers are particularly affected by shortfalls in this season. The drought was due to an accumulated rainfall deficit in the months preceding the Yala from January to April and significant deficits from June to August.

\section{Reservoirs in Galgamuwa Irrigation Division}

There are four major reservoirs and three medium reservoirs in Galgamuwa Irrigation division. These schemes come under the purview of the Director of Irrigation Kurunegala District and Irrigation Engineer Galgamuwa. Usgala Siyambalangamuwa and Maha Siyambalangamuwa reservoirs receive water from Siyambalangamuwa oya (tributary of Kala oya). Abakolawewa, Ataragalla, Palukadawala, Maha Galgamuwa and Maha Nanneriya reservoirs are situated in the river basin of Mee oya. Usgala Siyambalangamuwa and Maha Galgamuwa are ancient schemes which had been abandoned for a long time until they were restored by the Irrigation Department. Other reservoirs were constructed by the Irrigation Department in early 1960's.
Mee oya is complicated irrigation system with three major reservoirs which is connected by feeder canals. Abakolawewa is situated at upper level and across the Meeoya River. One feeder canal is connected Abakolawewa and Ataragalla reservoirs and another feeder canal is connected Ataragalla tank and Palukadawala tank. Maha Galgamuwa tank and Maha Nanneriya tanks are situated separately in the Mee oya river basin. Maha siyamblangamuwa is located at the upper part of the siyambalangamu oya and usgala siyambalangamuwa at lower part close to the Kala oya.

\section{Planning of cultivation season}

Planning of commencement date for cultivation is one of the main decisions to be taken at the cultivation meeting. Irrigation Engineers have to know whether a decision can be made on the basis of historical record on rain fall to commence cultivation with limited amount of water, anticipating the rain to come and fill up the reservoirs. The government officials such as District Secretary, Director of Irrigation, Irrigation Engineer, Officers from Agriculture Department, Agrarian Service Department, Banks and other relevant organizations attend cultivation meetings with farmers at the beginning of each cultivation seasons to draw up the cultivation calendar for the season. However, according to the way these cultivation meetings are held during the monsoonal rainy seasons, while the irrigation tanks are spilling. By that time most of the monsoonal rains and inter monsoonal rains have fallen and disappeared from farm lands and therefore become ineffective, in the command area. This process results in wastage of natural rain water. In order to remedy this situation, if the cultivation meeting is held before the inter monsoonal rain; well in advance of the rainy season it might be possible to use the rainfall for land preparation. 


\subsection{Planning of yala cultivation in the study area}

Mee oya system (Figure 02)

One Cultivation meeting was held for Abakolawewa, Ataraglla, Palukadawala reservoirs on 13/03/2012 and decisions were taken to start land preparation with utilizing rain water. Analyzing historical hydro meteorological data ( figure 1), farmers were explained rhythmic rainfall pattern to the area to decide the commencement date. According to the data, mid of March was the most appropriate time to start land preparation with rainfall. Therefore all parties agreed to start the cultivation on 15/03/2012. Rice variety of 3$31 / 2$ month and OFC were selected to establish the crops. Cultivation extents were decided according to the available water in reservoir and expected rainfall.

Due to Rehabilitation of the Usgala Siyambalangamuwa, tank was emptied and cultivation was abandoned.

\section{Maha Galgamuwa tank}

The Separate cultivation meeting was held on 20/03/2012 and same procedure was adopted as mee oya system to decide the commencement date of cultivation. Short term varieties of paddy were selected for full extent of command area.

\section{Maha Nanneriya tank}

Less rain fall received during march- may to Maha Nanneriya area. Therefore water collected in reservoir was not sufficient to cultivation of paddy. Irrigation officials and farmers were waiting until May 2012 to decide whether the cultivation is start or not. The capacity of the tank was 292 acft $(0.36 \mathrm{MCM})$ while total capacity is 1892 acft (2.33 MCM). This situation is $15 \%$ from total capacity. Finally I decided to call cultivation meeting to decide crop type suit to available water. Cultivation meeting was held on 08/05/2012 and decided to cultivate 150 acs (60 Ha) of peanut.
Peanut cultivation need only very less water and profit margin is very high than the paddy cultivation.

\section{Maha Siyambalangmuwa}

Harvesting of 2011/2012 Maha season delayed due to late cultivation of Maha season. Although the harvesting was completed before Sinhala New Year, could not commence the yala cultivation until this cultural ceremony is finished. The cultivation meeting was scheduled on 19/04/2012 and decided to start the cultivation on $21 / 04 / 2012$. The monsoonal rains were gradually reduced at the end of April and had to release water from reservoir for land preparation. The capacity of the reservoir was 1370 acft (1.61 MCM). Recorded Water duty for this area was 5 acft per acre(MCM/Ha) for yala season. Therefore we decided to cultivate 250 acs (101 Ha) of paddy under bethma system. Bethma system can be described as a portion of the field of suitable size selected and the rest is abandoned. The selected portion is then divided in to same number of shares in the whole field. The paddy tract selected for bethma was lying close to the tank bund. This system is traditional old cultivation systems which were observed under village tanks in early periods maintained by villagers themselves.

\section{Cultivation performance of the schemes under drought condition}

The farmers of all schemes have received a bumper harvest in this season. Over 100 busals of paddy harvest per acre $(5435 \mathrm{Kg} / \mathrm{Ha})$ was recorded and over hundred thousand rupees profit were taken from the OFC cultivation. It was found that it was possible to bring down to the duty of water less than Estimated duty of five acft per acre(MCM/Ha) even under drought condition by using rain water for land preparation. 
Table 01- Analysis of water consumption during Yala 2012

\begin{tabular}{|c|c|c|c|c|c|c|}
\hline Reservoir & $\begin{array}{c}\text { Extent } \\
\text { cultivated } \\
\text { (Ha) }\end{array}$ & $\begin{array}{c}\text { Capacity at } \\
\text { beginning } \\
\text { (MCM) }\end{array}$ & \begin{tabular}{|c} 
Total \\
Capacity \\
During the \\
season \\
(MCM)
\end{tabular} & $\begin{array}{l}\text { Balance } \\
\text { Capacity } \\
\text { at end of } \\
\text { the season } \\
\text { (MCM) }\end{array}$ & $\begin{array}{c}\text { Quantity } \\
\text { used for } \\
\text { cultivation } \\
\text { from the } \\
\text { tank (MCM) }\end{array}$ & $\begin{array}{c}\text { Water } \\
\text { used } \\
\text { (MCM/ } \\
\text { Ha) }\end{array}$ \\
\hline 1.Abakolawewa & 340 & 3.58 & 6.40 & 1.37 & 5.03 & 4.86 \\
\hline 2.Ataragalla & 220 & 2.53 & 4.43 & 1.19 & 3.23 & 4.84 \\
\hline 3.Palukadawala & 790 & 8.13 & 8.90 & 3.64 & 5.25 & 2.19 \\
\hline $\begin{array}{l}\text { 4.Maha } \\
\text { Galgamuwa }\end{array}$ & 176 & 4.87 & 5.43 & 3.56 & 1.88 & 3.5 \\
\hline $\begin{array}{l}\text { 5.Maha } \\
\text { Nanneriya }\end{array}$ & 60 & 0.36 & 0.69 & 0.37 & 0.33 & 1.76 \\
\hline $\begin{array}{l}\text { 6.Maha } \\
\text { Siyambalangmu } \\
\text { wa }\end{array}$ & 101 & 1.61 & 2.34 & 0.34 & 1.99 & 6.5 \\
\hline
\end{tabular}




\subsection{Analysis of water management practice adopted and income received}

According to the table 01, we can understand the water saving by using rain water to land preparation. Abakolawewa, Ataraglla, Palukadawala tanks belongs to Meeoya system and Maha Galgamuwa tank cultivation were started before Sinhala New Year. Rainwater used for land preparation. Duty of water was around 3 to 5 acft per acre.(MCM/HA) Maha Siyambalangamuwa cultivation started after Sinhala New Year and water has to be released from the tank because of the rain was disappeared. Total Water consumption was 6.5 acreft per acre (MCM/Ha). Comparing these two situations, it is clearly understood that saving of water by using rain fall for land preparation is nearly 1.5 acft per ac(MCM/Ha) Maha Nanneriya situation is deferent from the meeoya system and Maha siyambalangamuwa. Very less rainfall received and less runoff collected to the Nanneriya tank. To avoid decreasing the income level and living standard of the farmers belongs to the scheme, OFC cultivation was introduced to match with the available storage. Half an acre was allocated to one farmer to cultivate peanut and support provided to supply of seeds from agriculture department. Estimated water duty was 2.0 acft/ac (MCM/Ha) in beginning of the season but actual water duty was 1.76. Each farmer gets about $1000 \mathrm{~kg}$ of harvest and income nearly rupees one hundred thousand. Income from one acre of paddy land is about rupees twenty thousand. Comparing with paddy farmers, OFC farmers gets more profit than the paddy farmers.

\subsection{Strategies adopted to success the yala cultivation under drought condition}

Possibility of planning the date of commencement of cultivation according to this concept was examined by doing study of past meteorological and hydrological records which entirely depend on its own catchment. For this purpose Abakolawewa, Ataragalla, Palukadawala, Maha Galgamuwa, Maha Nanneriya and Maha Siyambalangamuwa schemes in Galgamuwa area was selected. Yala cultivation during 2012 was considered. Decision makers had to face many challenges to take correct decision at the cultivation meetings and during cultivation period. Following strategies were adopted to overcome these challenges.

- Conducted awareness programmes at the pre cultivation meeting and project committee meetings to educate farmers about prevailing weather patterns and available water storage of the reservoirs.

* Educated the farmers about cultivation methods, crop types and area to be cultivated to suit to dry weather condition and available water in the tank.

* Introduced the Traditional bethma system. Paddy tract selected for bethma was that lying close to the tank, thus helping to minimize conveyance losses and to conserve the available irrigation water.

- Cultivation meetings were held before the intermonsoonal rain, well in advance of the rainy season to be possible to use the rain fall for land preparation.

- Farmers reluctant to start cultivation just after maha harvesting. They like to relax between the both season. Encouraged and Advised to farmers to establish the crops before the New Year festival.

* Technological support from agriculture department, supporting services from Agrarian service department, credit facilities from Banks, Irrigation facilities from Irrigation Department, Insurance and Trading facilities From Other service providers were coordinated by the project managers of Irrigation management division and Irrigation department.

* Discussions were held with farmers before every rotational Irrigation issues by the Irrigation officials, identified short comings and attended the conflict situations to solve from next issue.

- Aware the farmers about possibility of cultivation of short term crops in mid seasons and start of next maha season on time. 


\section{Conclusions}

Increased scarcity of irrigation water persuades us to introduce improved management in irrigation schemes to obtain the optimum use of water. Saving water in the rainy season, by implementing tactics to issue less irrigation water enables an increase in the water availability for dry season crops. The study which was conducted during yala 2012 in Galgamewa area demonstrate the methodology to decide the most appropriate date for cultivation, in order to minimize the irrigation water requirement. In other words this ensures the maximum utilization of rain water during the cultivation season.

\section{Acknowledgements}

I would like to thank retired Director of Irrigation Eng W. Gamage for encouraging me for this study.

\section{References}

Dharmasena G T, 1990" Planning of Irrigation to Optimize the effective rainfall" IESL. 